Ann. Biol. anim. Bioch. Biophys., 1978, 18 (4), 787-791.

\title{
Studies on the purification of gonadotrophin from dogfish (Scyliorhinus canicula L.) pituitary glands
}

\author{
par J. P. SUMPTER, B. K. FOLLETT, J. M. DODD \\ Department of Zoology, Brambell Laboratories, \\ University College of North Woles, Bangor, Gwynedd, LL57 2UW, U. K.
}

Summary. Gonadotrophin (GTH) was purified from the dogfish (Scyliorhinus canicula) by first preparing a glycoprotein fraction followed by chromatography on Con A-Sepharose and CM-cellulose. GTH and TSH activities were assayed using chicks and quail. Although CM-cellulose produced two peaks of GTH activity, their biological activities were similar, suggesting that the dogfish produces one GTH which is particularly LH-like.

\section{Introduction.}

While it is now widely accepted that two gonadotrophins, resembling mammalian $\mathrm{LH}$ and $\mathrm{FSH}$, are produced by the pituitaries of birds, reptiles and amphibians, most work with bony fishes suggests the presence of only one gonadotrophin in this class of vertebrates (e. g. Burzawa-Gérard, 1971 ; Donaldson ef al., 1972 ; BurzawaGérard ef al., 1975 ; Breton ef al., 1976). This conclusion is, however, being questioned in recent publications (e. g. Idler ef al., 1975 ; Pierce et al., 1976 ; Farmer and Papkoff, 1977). No information exists on the gonadotrophin(s) of the cartilaginous Elasmobranch fishes and the present study presents some results on the purification of this hormone from the lesser spotted dogfish (Scyliorhinus canicula).

\section{Materials and methods.}

Pituitary glands were collected from fresh, sexually mature dogfish caught in the middle of the breeding season when pituitary gonadotrophin content is at its highest (Sumpter, 1976), and stored at $-20^{\circ} \mathrm{C}$. Two batches of material were processed, each containing ca. 1000 lobes. Both contained approximately equal numbers of each sex. Only the ventral lobes were processed, as this is the main, if not the only, pituitary lobe containing gonadotrophin.

An initial glycoprotein extract (GTN) was prepared essentially according to Stockell Hartree (1975). Affinity chromatography on Con A-Sepharose was then carried out according to Idler ef al. (1975) except that $1 \mathrm{mM} \mathrm{MnCl}$ and $1 \mathrm{mM} \mathrm{CaCl}$ were added to the buffers. lon-exchange chromatography of the adsorbed gonadotro- 
phic fraction (Con A-2) was carried out on CM-cellulose (Whatman CM-32) according to Stockell Hartree (1975).

Gonadotrophic activity was assayed both by estimating the uptake of radioactive phosphorus into the testes of day-old chicks (Follett and Farner, 1966), and by measuring androgen release from isolated quail testicular cells (Maung and Follett 1977). Thyrotrophin was estimated by the uptake of phosphorus into the thyroids of day-old chicks (Scanes and Folleft, 1972). Mean potencies and 95 p. 100 confidence limits were calculated by standard bioassay statistics.

\section{Results.}

All the gonadotrophic and thyrotrophic activity in the ventral lobe was precipitated in the glycoprotein fraction (GTN). Following chromatography of this GTN on Con A-Sepharose, most emerged unadsorbed (Con A-1), but a small peak of adsorbed material was eluted by a buffer containing glucoside. This second peak (Con A-2) contained the vast majority (ca. $90 \mathrm{p}$. 100) of the gonadotrophin.

The TSH activity was also largely bound to Con A-Sepharose, although there did appear to be some separation from the GTH activity as only 60 p. 100 of the TSH activity recovered was in Con A-2. With high recoveries of gonadotrophin and the elimination of much inactive protein, the increase in potency averaged 17 -fold after Con A-Sepharose chromatography.

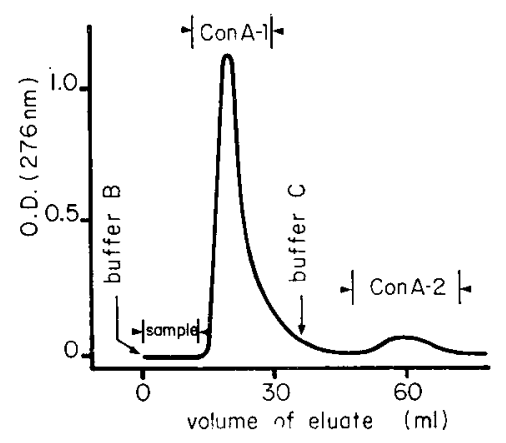

FIG. 1.

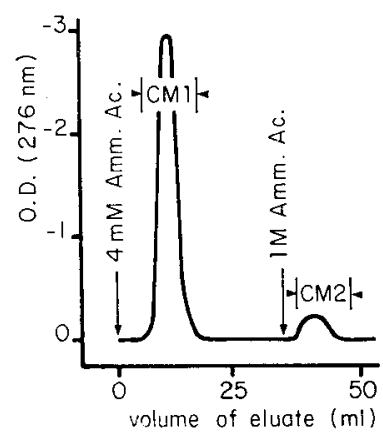

FIG. 2.

FIG. 1. - Elution profile of $500 \mathrm{mg}$ GTN on a Con A-Sepharose column $(1.25 \times 15 \mathrm{~cm})$. The flow rate was $10 \mathrm{ml} / \mathrm{hr}$. Fractions were pooled as indicated. Buffer $B$ was $0.05 \mathrm{M} \mathrm{Tris}-\mathrm{Cl}, \mathrm{pH} 7.7 ; 0.5 \mathrm{M} \mathrm{NaCl}$; $0.2 \mathrm{mM}$ dithiothreitol; $1 \mathrm{mM} \mathrm{MnCl} 2 ; 1 \mathrm{mM} \mathrm{CaCl}$. Buffer $\mathrm{C}$ contained $0.15 \mathrm{M} \alpha$-methyl-D-glucoside in addition.

FIG. 2. - Elution profile of $11.8 \mathrm{mg}$ Con A-2 on a CM-cellulose column $(1.2 \times 5 \mathrm{~cm})$. The flow rate was $20 \mathrm{ml} / \mathrm{hr}$. Fractions were pooled as indicated.

To see if Con A-2 contained more than one gonadotrophin, one batch was applied to a column of CM-cellulose. Figure 2 shows the results of this step. About 90 p. 100 of the protein was not adsorbed and was eluted in the first fraction (CMI). When the buffer was changed to IM ammonium acetate a second, much smaller, peak emerged (CM2). 
The gonadotrophic activity was split equally between $C M 1$ and $C M 2$, with the result that $C M 2$ had a specific activity much greater than $C M 1(1.04$ and $0.08 \times \mathrm{NIH}$ LH-S19, respectively, as measured by the ${ }^{32} \mathrm{P}$-chick bioassay). When assayed on the same day in the isolated testicular cell assay, the same solutions gave activities of 1.00 and $0.06 \times \mathrm{NIH}-\mathrm{LH}-\mathrm{S} 19$ respectively. The biological activities of various dogfish gonadotrophic fractions, from the same purification, in both the ${ }^{32} \mathrm{P}$-chick and isolated testicular cell bioassays, are shown in figure 3. In all cases NIH-LH-S19 was used
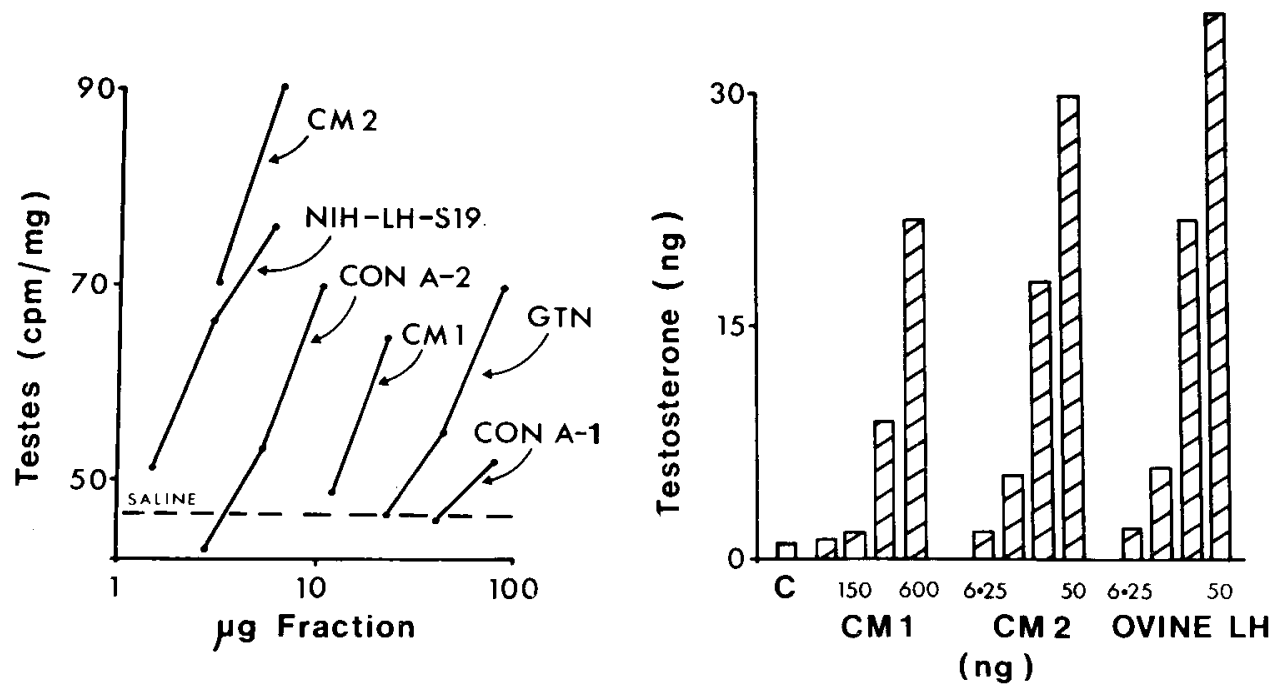

FIG. 3. - The biological activities of various partially-purified dogfish gonadotrophic fractions in the 32p-chick (left) and isolated quail tesficular cell (right) bioassays.

\section{TABLE 1}

The weights and biological potencies of fractions from one purification Gonadotrophic activity in $\mu \mathrm{g} \mathrm{NIH-LH-S19/mg;} \mathrm{Thyrotrophic} \mathrm{activity} \mathrm{in} \mu \mathrm{g} \mathrm{NIH-TSH-S8} / \mathrm{mg}$; with 95 p. 100 confidence limits

GTH

TSH

GTN from 990 Ventral Lobes.

Con A-Sepharose Chromatography

Con A-1

Con $A-2 \ldots \ldots \ldots \ldots \ldots \ldots$

Rechromatography of $80 \mathrm{mg}$ Con A-1

Con $A-1 \ldots \ldots \ldots \ldots \ldots \ldots \ldots$

Con $A-2 \ldots \ldots \ldots \ldots \ldots \ldots \ldots$

Combined Con A-2 ...........

CM-Cellulose Chromatography

CM1

$\mathrm{CM} 2$
365.9

115.0

13.63

40.56

6.85

18.96
6.6
0.70
54.5 in testicular cell assay
(967.5-1 194)

$29.7(22.1-40.0)$

$2.59(1.91-3.52)$

$40.0(5.36-103.9)$

$288.1(186.3-433.6)$

$16.9(0.7-29.3)$

$234.5(143.6-248.2)$

275.4 (211.8-358.1)

$11.57(9.07-14.75)$

1000 in testicular cell assay 
as the common standard. All fractions gave dose-response curves parallel with the standard.

Table 1 shows that $700 \mu \mathrm{g}$ of an active gonadotrophin (CM2) were obtained from 1000 ventral lobes. TSH was purified along with the gonadotrophic activity, although no positive attempt was made to separate the two activities. When a saline extract of 400 ventral lobes was chromatographed on Sephadex G-100 $(2.5 \times 100 \mathrm{~cm})$ all the biological activity was retarded and emerged at a point similar to that for rat FSH.

\section{Discussion.}

Glycoprotein extraction, followed by affinity chromatography on Con A-Sepharose, proved successful in concentrating the GTH and TSH activities while eliminating much protein. All the initial biological activity could be recovered in the Con A-2 fraction if conditions were chosen correctly. The behaviour of dogfish gonadotrophin in ammonium acetate : ethanol mixtures, and on Con A-Sepharose, indicates that it is a glycoprotein.

The results of chromatography on CM-cellulose, a classical method of separating $\mathrm{LH}$ from FSH, appear to suggest that the dogfish produces two gonadotrophins. However, bioassays do not support this view. The ${ }^{32} \mathrm{P}$-uptake method measures both LH and FSH, at least in birds and mammals (Scanes and Follett, 1972), while the testicular cell assay measures only higher vertebrate LH. As the ratio of gonadotrophic activity in $C M 1$ to that in $C M 2$ is similar in both assays, it would appear that there is only one gonadotrophin with an LH-like activity. If a second FSH-like gonadotrophin had been present in CM1, one would have expected the ratio to have varied between the two bioassays. The reason for the existence of two peaks may simply be that CM-cellulose only adsorbs about 50 p. 100 of dogfish GTH. CM-cellulose is often a poor separator of LH and FSH.

Although the results suggest that the dogfish produces an LH-like gonadotrophin, no firm conclusion can be drawn since the intrinsic activities of gonadotrophins may change markedly when tested outside the same class of vertebrates (e. g. Light and Midgley, 1976). Also, a hormone may be potent in a bioassay specific for one of the two gonadotrophins, but be inactive in a different bioassay for that same gonadotrophin. This is illustrated by the Tilapia gonadiotrophin (Farmer and Papkoff, 1977), which was potent in a rat Leydig cell assay but not in stimulating ovulation in Xenopus. The studies reported here, because they were conducted on a batch of pifuitaries from mature fish of both sexes, add nothing to the concept that a sexual difference may exist between male and female gonadotrophin, nor to the possibility that the gonadotrophin may change during ontogeny.

Many of the reports of the purification of fish gonadotrophic hormones have noted that they appear more fragile than mammalian gonadotrophins, and Breton ef al. (1976) consider that spontaneous dissociation may occur in both trout and carp gonadotrophins. Losses of biological activity in the purified dogfish fractions have also been encountered, although this may be due to aggregation rather than disso- 
ciation of the molecules. Storage in solution at $-70^{\circ} \mathrm{C}$, rather than in the dry form at $-20^{\circ} \mathrm{C}$, seems to have alleviated the problem.

Symposium sur la Reproduction des Poissons

Paimpont, France, 19-21 septembre 1977.

Résumé. Les gonadotrophines (GTH) de la roussette (Scyliorhinus canicula L.) ont été purifiées par préparation d'une fraction glycoprotéique séparée par chromatographie sur Con A-Sepharose et CM-cellulose. Les activités GTH et GTSH ont été testées sur poussin ef caille. Bien que la chromatographie sur $\mathrm{CM}$-cellulose produise deux pics d'activité gonadotrophique, leurs activités biologiques sont similaires, laissant penser que la roussette produit une gonadotrophine très proche de LH.

\section{References}

BRETON B., JALABERT B., REINAUD P., 1976. Purification of gonadotrophin from rainbow trout (Salmo gairdnerii Richardson) pituitary glands. Ann. Biol. anim. Bioch. Biophys., 16, 25-36.

BURZAWA-GERARD E., 1971. Purification d'une hormone gonadotrope hypophysaire de poisson téléostéen, la carpe (Cyprinus carpio L.). Biochimie, 53, 545-552.

BURZAWA-GÉRARD E., GONCHAROV B. F., FONTAINE Y. A., 1975. L'hormone gonadotrope hypophysaire d'un poisson chondrostéen, l'esturgeon (Acipenser stellatus Pall.). 1. Purification. Gen. comp. Endocr., 27, 289-295.

DONALDSON E. M., YAMAZAKI F., DYE H. M., PHILLEO W. W., 1972. Preparation of gonadotropin from salmon (Oncorhynchus tschawytscha) pituitary glands. Gen. comp. Endocr., 18, 469-481.

FARMER S. W., PAPKOFF H., 1977. A teleost (Tilapio mossambica) gonadotropin that resembles luteinizing hormone. Life Sci., 20, 1227-1232.

FOLLETT B. K., FARNER D. S., 1966. Pituitary gonadotrophin in the Japanese quail (Coturnix coturnix japonica) during photoperiodically induced gonadal growth. Gen. comp. Endocr., 7, 125-131.

IDLER D. R., BAZAR L. S., HWANG S. J., 1975. Fish gonadotropin(s). II. Isolation of gonadotropin(s) from chum salmon pituitary glands using affinity chromatography. Endocr. Res. Commun., 2, 215-235.

III. Evidence for more than one gonadotropin in chum salmon pituitary glands. Endocr. Res. Commun., 2, 237-249.

LIGHT P., MIDGLEY A. R. Jr., 1976. Competition for the in vitro binding of radioiodinated human follicle - stimulating hormone in reptilian, avian and mammalian gonads by nomammalian gonadotropins. Gen. comp. Endocr., 30, 364-371.

MAUNG Z. W., FOLLETT B. K., 1977 . Effects of chicken and ovine LH on androgen release and cyclic AMP production by isolated cells from the quail testis. Gen. comp. Endocr., 33, 242-253.

PIERCE J. G., FAITH M. R., DONALDSON E. M., 1976. Antibodies to reduced S-carboxymethylated alpha subunit of bovine luteinizing hormone and their application to study of the purification of gonadotropin from salmon (Oncorhynchus tschawytscha) pituitary glands. Gen. comp. Endocr., 30, $47-60$.

SCANES C. G., FOLLETT B. K., 1972. Fractionation and assay of chicken pituitary hormones. Brit. Poult. Sci., 13, 603-610.

STOCKELL HARTREE A., 1975 . Purification of human pituitary glycoprotein hormones, 380-389. in O'MALLEY B. W., HARDMAN J. G., Methods in Enzymology, 37, Hormone Action, Part B, Peptide hormones, Acad. Press, New-York,

SUMPTER J. P., 1976. An annual cycle of plasma œstradiol and testosterone, and pituitary gonadotrophin, in the female dogfish, Scyliorhinus canicula. Gen. comp. Endocr., 29, 268-269. 